\title{
Oncologic surveillance for subjects with biallelic mismatch repair gene mutations-10 year follow-up in a kindred
}

\author{
Carol A Durno ${ }^{1,2,3^{*}}$, Melyssa Aronson ${ }^{1}$, Uri Taborii ${ }^{2,4}$, David Malkin ${ }^{2,4}$, Helen Chan ${ }^{2,4}$, Steven Gallinger ${ }^{1}$ \\ From 14th Annual Meeting of the Collaborative Group of the Americas on Inherited Colorectal Cancer \\ Dallas, TX, USA. 12-13 October 2010
}

\section{Background}

Lynch syndrome (LS) is caused by heterozygous germline mutations in the DNA mismatch repair (MMR) genes and is a highly penetrant autosomal dominant condition. A novel childhood cancer syndrome caused by biallelic germline MMR gene mutations and characterized by brain tumors, leukemias, gastrointestinal (GI) polyposis, GI cancer and café-au-lait spots (CALS) has been described. We reported the first biallelic kindred in which 2 of 3 siblings proven to have a homozygous germline MLH1 mutation, developed early-onset GI cancer. In contrast to LS with clear GI screening and surveillance recommendations, there are no recommendations for surveillance of individuals with biallelic mutations and no literature describing the long term outcome.

\section{Aim}

To prospectively describe long-term outcome of our two young patients with biallelic MMR mutations, and to develop a generic cancer screening protocol for other patients with biallelic MMR mutations.

\section{Methods}

On the basis of the molecular results, the 2 surviving sisters and parents of a deceased child with metastatic duodenal cancer began a surveillance protocol based on our crude estimates of cancer risks and available cancer screening modalities.

\section{Results}

During endoscopic screening the youngest sister developed colonic polyps with high grade dysplasia and underwent a subtotal colectomy with ileorectal anastomosis. At 11 years she developed polyps in the duodenum with low grade dysplasia which were excised endoscopically. At 13 years of age, surveillance MRI revealed a left parieto-occipital anaplastic astrocytoma enabling total resection. Endoscopy in the older sister who had a subtotal colectomy with ileorectal anastomosis at 9 years of age for metastatic colorectal cancer has low grade polyps in the duodenum, ileum and rectum which were excised endoscopically. Gynecological follow-up of both sisters with annual pelvic ultrasounds have shown functional ovarian cysts. All neoplastic lesions identified during surveillance were asymptomatic at diagnosis. The sisters are currently fifteen and seventeen years old with no evidence of disease 10 years after their brother's diagnosis. The parents (43 and 44 years) have annual colonoscopy with no evidence of polyps or cancer. Gynecological screening for the mother has not revealed any abnormalities. Based on our experience to date and review of available literature, we have developed the screening guidelines shown in Table 1.

\section{Conclusions}

Biallelic carriers who participated in oncologic surveillance had presymptomatic neoplasms identified and treated. These siblings are alive with no evidence of disease at 10-year follow-up. Aggressive surveillance in biallelic MMR carriers is feasible, allows early detection and improves long-term survival.

\footnotetext{
* Correspondence: Carol.durno@sickkids.ca

'Zane Cohen Familial Gastrointestinal Cancer Registry (FGICR) and

Department of Surgery, Mount Sinai Hospital, Ney York, NY, USA

Full list of author information is available at the end of the article
}

(c) 2011 Durno et al; licensee BioMed Central Ltd. This is an open access article distributed under the terms of the Creative Commons Attribution License (http://creativecommons.org/licenses/by/2.0), which permits unrestricted use, distribution, and reproduction in any medium, provided the original work is properly cited. 
Table 1 Screening Guidelines

\begin{tabular}{ll}
\hline Cancer & Recommendations \\
\hline Colon & Colonoscopy yearly* \\
Upper Gl Tract and small bowel & EGD yearly* \\
& Video capsule endoscopy* \\
Brain+ & MRI brain q 6 months \\
Leukemia+ & CBC, DNA for T-cell and B-cell rearrangement, serum LDH q 3 to 6 months \\
Lymphoma+ & Abdominal ultrasound at birth or diagnosis \\
Urinary tract &
\end{tabular}

EGD, Esophagogastroduodenoscopy.

*beginning at 3 years of age or at diagnosis with frequency determined by baseline findings.

+if diagnosed prenatally brain, leukemia/lymphoma screening should commence at birth.

\section{Author details}

${ }^{1}$ Zane Cohen Familial Gastrointestinal Cancer Registry (FGICR) and

Department of Surgery, Mount Sinai Hospital, Ney York, NY, USA.

${ }^{2}$ Department of Pediatrics, Hospital for Sick Children, University of Toronto,

Toronto, Ontario, Canada. ${ }^{3}$ Division of Gastroenterology, Hepatology and

Nutrition, Hospital for Sick Children, University of Toronto, Toronto, Ontario,

Canada. ${ }^{4}$ Division of Hematology/Oncology, Hospital for Sick Children,

University of Toronto, Toronto, Ontario, Canada.

Published: 10 March 2011

doi:10.1186/1897-4287-9-S1-P11

Cite this article as: Durno et al:: Oncologic surveillance for subjects with

biallelic mismatch repair gene mutations-10 year follow-up in a

kindred. Hereditary Cancer in Clinical Practice 2011 9(Suppl 1):P11.

Submit your next manuscript to BioMed Central and take full advantage of:

- Convenient online submission

- Thorough peer review

- No space constraints or color figure charges

- Immediate publication on acceptance

- Inclusion in PubMed, CAS, Scopus and Google Scholar

- Research which is freely available for redistribution

Submit your manuscript at www.biomedcentral.com/submit
C Biomed Central 